\title{
Perception of Accountants and Accounting Profession in two Countries: Different Terms of Economy and Culture
}

\author{
Irena Jindrichovska $^{1}$, Dana Kubickova ${ }^{2}$
}

\begin{abstract}
:
In this study we analyse the perception in the role of accountants and accounting profession in different national environments - in the Czech Republic and China. We suggest that the features of continental accounting formed the specific characteristics of the Czech accounting, where the main role of accountants is assumed to be the tax calculation and optimization.

On the other hand, change of economic system, cultural and historical conditions of the Peoples Republic of China (PRC) suggest different recourse. We assume that transformation of Chinese economic system to market principles could cause changes in recognized accounting principles and practises.

Our results confirmed that there exist different opinions on the role of accountants in business and in position to selected business problems depending on nationality of respondents. We can also see some similar elements in both national economies.
\end{abstract}

Keywords: accounting profession, financial reporting, national environment, cultural differences.

\footnotetext{
${ }^{1}$ Corresponding author: Irena Jindrichovska, Anglo-American University Prague, irena.jindrichovska@aauni.edu,irena.jindrichovska@seznam.cz

${ }^{2}$ University of Finance and Administration, Prague
} 


\section{Introduction}

According to the AAA, accounting is "... the process of identifying, measuring, and communicating economic information to permit informed judgments and decisions by users of the information." ${ }^{3}$ Accounting profession represents qualified professionals, who are dealing with accounting at various levels being it within a small firm, where one accountant may perform the accounting tasks including accounts keeping and reporting. In large enterprises there may be several specialized accountants responsible for cost accounting, internal control, reporting and related tasks. Small firms can also outsource accounting services from external agency, which will perform accounting function for several firms.

Perception on accounting and accounting profession has been recently researched in many cultures most often, however, in developed societies of Western Europe and North America. Recent studies dealing with perception of accounting and accounting profession were written e.g. in the US by Allen, 2004, in Ireland by Byrne \& Willis, 2005 , and by Buchan, 2005. Majority of these studies are involved with professional requirements and with ethical issues. Carnegie \&Napier (2010) have written critical study assessing the position of traditional accountants and business professional and its changes after Enron scandal.

Our study is not so much involved in critique of accounting profession, but it deals more with the perception of its content in Eastern Europe and in China. The importance of accounting information and the position of the accountant profession is determined by the economic system. Accounting has different position in centrally planned economy and in the market based system. In switching from a centrally managed to a market economy, accounting must be transformed as an element of the economic system, e.g. Schroll, 1995; World Bank, 2003. Both economic systems Czech and Chinese are undergoing similar process in terms of transformation of a system centrally controlled to a system operating on market principles.

Accounting concept and the accounting profession should therefore display certain similar or identical features. However, an integral element of every economic system is its historical experience and inherited or gained cultural specifics that are projected in every specific activity of a given country or region. These particularities can either support or block the process of transformation. The primary stimulus for carrying out this research was the intention to map the situation around accounting and accounting profession in the two countries. Because of different cultural and historical background of the countries we expect that, through our qualitative questionnaire based research, we will find certain similar features but also differences in understanding the position of accounting and perception of accounting

${ }^{3}$ https://www.business-case-analysis.com/accountant.html\#accountant-roles accessed on 24.9.2017. 
profession. The text of the paper is structured as follows: the next section explains the degree and special features of development of the economic system development together with the main of the macroeconomic characteristics of economic background as a foundation accounting profession and accounting way of thinking. The second part deals with the characteristics of accountants and accounting profession and its position in Chinese economic system. The third section presents the used methods in line with goal of our research. The fourth section presents results of our research and provides interpretation. The discussion and limitations of our findings are explained in the fifth part. Conclusion and suggestions for further research are summarised in the last section.

\section{Background and Macroeconomic Conditions}

\subsection{CHINA}

China has already, for several decades, belonged to the group of fast growing countries and it is a member of so called BRICK. Much has been written about the rapidly growing Chinese economy since 1990s, ranging from sharp criticism of its ideology on one side to admiration of economic results on the other one. Nobel Prize winner Paul Krugman criticised China repeatedly since 1990s (Krugman, 1994, 2010 and 2011). Positive perception of China comes from the recognition of Chinese ability to generate money, which is supported by material economic results. From macroeconomic point of view, Chinese economy is now in a healthy state.

Continuing strong external demand is pushing exports of merchandize as well as industrial production in virtually all sectors. Strong domestic demand is projecting into improved dynamics in the manufacturing sector. Current macroeconomic situation can be summed up in key macroeconomic indicators as follows:

Table 1. Macroeconomic Characteristics of Recent Development

\begin{tabular}{|l|l|l|l|l|l|}
\hline & $\mathbf{2 0 1 1}$ & $\mathbf{2 0 1 2}$ & $\mathbf{2 0 1 3}$ & $\mathbf{2 0 1 4}$ & $\mathbf{2 0 1 5}$ \\
\hline Economic growth of GDP intra year & 9.5 & 7.9 & 7.8 & 7.3 & 6.9 \\
\hline GDP (USD billon) & 7.592 & 8.575 & 9.694 & 10.480 & 10.925 \\
\hline Population in million & 1.347 & 1.354 & 1.361 & 1.368 & 1.375 \\
\hline GDP per capita & 5.635 & 6.333 & 7.124 & 7.662 & 7.948 \\
\hline Export (USD bill) & 1.898 & 2.049 & 2.209 & 2.342 & 2.272 \\
\hline Import (USD bill) & 1.744 & 1.819 & 1.952 & 1.959 & 1.681 \\
\hline Balance (export/import) & 1.088 & 1.126 & 1.132 & 1.196 & 1.352 \\
\hline Inflation rate (CPI) & 5.4 & 2.6 & 2.6 & 2.0 & 1.4 \\
\hline Consumption (Annual variation) & 11.0 & 9.1 & 7.3 & 7.7 & 7.5 \\
\hline Public debt (\% of GDP) & 14.7 & 14.4 & 14.6 & 14.9 & 15.5 \\
\hline
\end{tabular}

Source: China statistical yearbook and own elaboration 
China is now the second biggest economy and it is doing quite well since the financial crisis as China exited the financial crisis of 2008 in good condition. The country GDP grew above 9\%, having low inflation and a sound fiscal position with public debt of less than 15 per cent of GDP.

Although Chinese growth slowed down to from 9.5 in 2011 to 6.9 per cent in 2015 , trade balance remains positive as export extends country import. Inflation in the country is low in general and consumption is growing modestly. According to China economic outlook published by Focus economic, "President Xi Jinping stressed that the financial sector must serve the real economy and that the government must contain financial risks and implement bolder economic reforms." 4

Moreover, the volume of its international trade is growing as the country does not rely on import of technically advanced products and it is cultivating own R\&D. This effort started already in 1990s (Qian, \& Stiglitz, 1996). As for economy at large, former socialist model is being gradually transformed to new market economy (Stiglitz, 2008).

China is now accenting its internal growth and development, which is based on development of its own abilities starting with building industrial centres and educating and cultivating own workforce (Wang, \& Mao, 2017). Many students study abroad in developed Western countries as well as in the countries of the formal Eastern Block, which assures certain balance (Wang, \& Guthrie, 2004). Motivation of Chinese students studying abroad has always been high. Large trading surplus and balanced budget provides resources and opportunities for further advancement.

Moreover, it has been historically known, that Chinese people being brought up in the old eastern Confucian tradition are hardworking, modest and have respect for hierarchy i.e. recognize their own place in society (Yihong, Yuan, Ying, \& Yan, 2007; Thalassinos, 2008; Liapis and Thalassinos, 2013; 2014; Thalassinos et al., 2010; 2014).

Supporting element is also the education. Chinese education has been largely internationalized since late 1990s. Development of higher education in China is summarised by Huang (2003). After 1952, the Soviet communist model was introduced into the People's Republic of China and it dominated China's higher education development almost until the end of the 1970s. Subsequently two waves of changing approach to internationalization of Chinese education have taken place. The first major change came in 1978, when the state ministry of education decided to broaden the education internationally. The pragmatic decision was to send students and scholars abroad. The students were expected to focus especially on the

\footnotetext{
${ }^{4}$ http://www.focus-economics.com/countries/china

China statistical yearbook 2016, accessed by 7.7.2017

http://www.stats.gov.cn/tjsj/ndsj/2016/indexeh.htm
} 
fields of science, engineering, agriculture, and medicine. The intent was to gain more educated manpower at a higher level for the national economy. Chinese system was also becoming more decentralizes after 1984, when the centre delegated more authorities and responsibilities for dispatching scholars and students abroad to other agencies in the central government, provincial governments, and institutions. Subsequent wave of educating effort started in 1993 with increased outflow of Chinese society members. There has arisen a problem of attracting Chinese scholars and students back home to China. The issue of increasing outflow of qualified personnel abroad remains until now. As in most developing countries it seems that the "brain drain", as well as the ability to benefit from transnational education. However, the situation is changing due to rising power of Chinese economy within the political and economic scheme of the world.

The OECD report of 2016 entitled Education in China a snapshot provides a broad overview and great details of how China's education system operates. China has the largest education system in the world. It holds the belief that education is the basis of national development and modernisation (OECD 2016, 12). There are four parts of China already involved in the Programme for International Student Assessment, or PISA. The Chinese government assigns a high value to education. The education scheme has been reformed several times. The government uses laws and regulations to protect access to education, and to guarantee its high-quality. The Law on Compulsory Education was enacted, in 1986representing compulsory nine years of education staring at the age of six.

The Ministry of Education formulates the Five-Year Guideline for National Education Development. Subsequently students continue with secondary school or vocational training. University education lasts for four to ten years. (Four years are typical for bachelor degree, more years for master and $\mathrm{PhD}$ degrees). As it has been already underlined in previous paragraphs many Chinese students frequently study abroad to enhance the knowledge and skills for their national economy.

As it has been stressed by the Chinese government, the Chinese do not like to waste their resources needlessly and as people they are very modest and hard working. However, in Chinese economy all activities are primarily subject to lowering costs and increasing volume of production. It is known that Chinese do not care very much for natural environment and thus big problems are waiting especially in agglomerations and industrial centres. Obviously further economic and social development of China can become an issue of internal politics moderated by international relations to major political and economic superpowers like USA and Russia and trading blocks, like NAFTA and EU and ASEAN. Full acceptance of China to the world economic community is conditioned by reaching status of market economy. This is hindered by four unfulfilled criteria ${ }^{5}$ : lack of transparency, removal

\footnotetext{
${ }^{5}$ The following criteria of admittance are formulated in Council Regulation (EC) No 905/98: (1) companies decide on the price, costs and inputs, including raw materials, technology and
} 
of non-tariff measures preventing entry of international companies on Chinese market tariffs, significant government interventions and lack of respect of private property. As a negative factor is perceived also the system of five-year plans that does not create room for full influence of market forces and functioning of free market mechanisms (Kloudová, 2006). ${ }^{6}$

To fulfil the second criterion of transition from planned economy to free market a conversion to the new accounting standards was realised. These new Chinese Accounting Standards (ChAS) are adopting the principles contained in International Financial Reporting Standards (IFRS) and are a part of the Chinese standards were adopted on January 1st, 2007. Although they do not comply fully with the IFRS, they are substantially converged. The European Commission permitted Chinese issuers to use the ChAS in the European Community for a transitional period of up to three years. The new ChAS were adopted for all listed companies and they were supposed to be gradually assumed by all other companies and enterprises. It is supposed that the ChAS will be updated in line with development of IFRS in the next years (ICAS, 2010).

Implementation of IFRS in the Chinese accounting system is the tool, which has transformed the "rules-based" procedures to a more "principle-based" system. The previous standards have been essentially highly prescriptive. In addition, they reflected different industry specifics, which caused great differences between individual industrial versions of standards in use. These differences were the main cause of difficulties in preparation of meaningful consolidated accounts (ICAS, 2010).

The implementation of principle-based standards places additional demands in terms of further education on accountants as well as on the audit profession. Changes in Chinese accounting system and concurrent changes in the whole economic system were reflected in thinking of professional accountants and corporate financial managers.

\title{
2.2 Czech Republic
}

\begin{abstract}
labour costs, production, sales and investments based on market signals reflecting supply and demand Without major State interference in this matter; the cost of the most important inputs must be based on market value; (2) the Company has clear and unambiguous accounting records audited by independent auditors in line with International Accounting Standards and used in all areas; (3) the cost of production and the financial situation of companies are not subject to significant distortions caused by the former non-market economy system, in particular as regards depreciation of assets, other depreciation, exchange and offsetting; (4) companies are subject to bankruptcy and property laws that guarantee legal certainty and stability for the functioning of companies; (5) conversion of exchange rates shall be made at market rates.

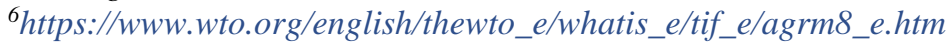


The Czech Republic is a transitional country within the group of CEE countries (countries of Central and Eastern Europe). The CR is a member of the OECD since December 21, 1995. The socio-economic and political background is characterized by changing from a centrally-planned to a market economy. One can expect influences of previous arrangements to survive for some time. IFRS adoption has been influenced by change of ownership structure, with 58 per cent of companies in foreign hands (Ernest, 2014). This has been generated by previous mass privatization and the ongoing influence of FDIs, which has influenced the scope of implementation or adoption of IFRS in the Czech Republic.

The Czech Republic is a member of the EU, which still demonstrates much diversity (MacGregor and Pelikánová, 2017) and has not yet moved for the full harmonization regarding accounting. Hence in the Czech Republic, both the EU law and Czech national law (MacGregor and Pelikánová, 2014) apply and consequently, the system of IFRS is implemented as a system of reporting for the companies listed on EU capital markets while the other companies must comply with the Czech accounting standards (CAS). The CAS are national, rules-based standards with some IFRS elements. The history of the CAS is like Chinese ChAS in the field of industrial variation of standards, which in its weaker form has persisted to the present.

Economic development of the Czech Republic should be assessed in the context of developments in other countries due to the economic crisis that began in 2008 and affected most countries, especially developed countries. It is considered the deepest crisis in the post-war period. As for the Czech Republic, after a deep recession in 2009 there came only a moderate recovery in 2010, and in 2011 growth momentum was already lost - as in most EU countries.

\section{Figure 1. Macroeconomic trends}

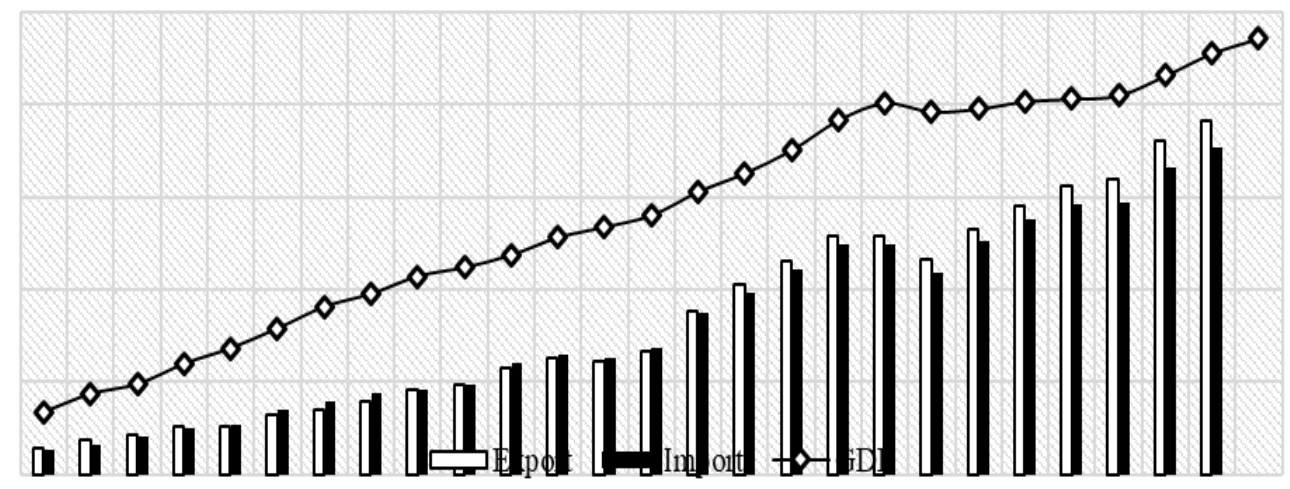

Source: $h t t p s: / / v d b . c z s o . c z /$

Czech international trade is diversified, but the main export sectors remain machinery and transportation industries. The Ministry of Trade and Industry is supporting exporters by removing barriers to trade, and simplification of the access 
to information and by government missions strives to increase the volume of trade and increase its diversity

Figure 2. Foreign Direct Investments

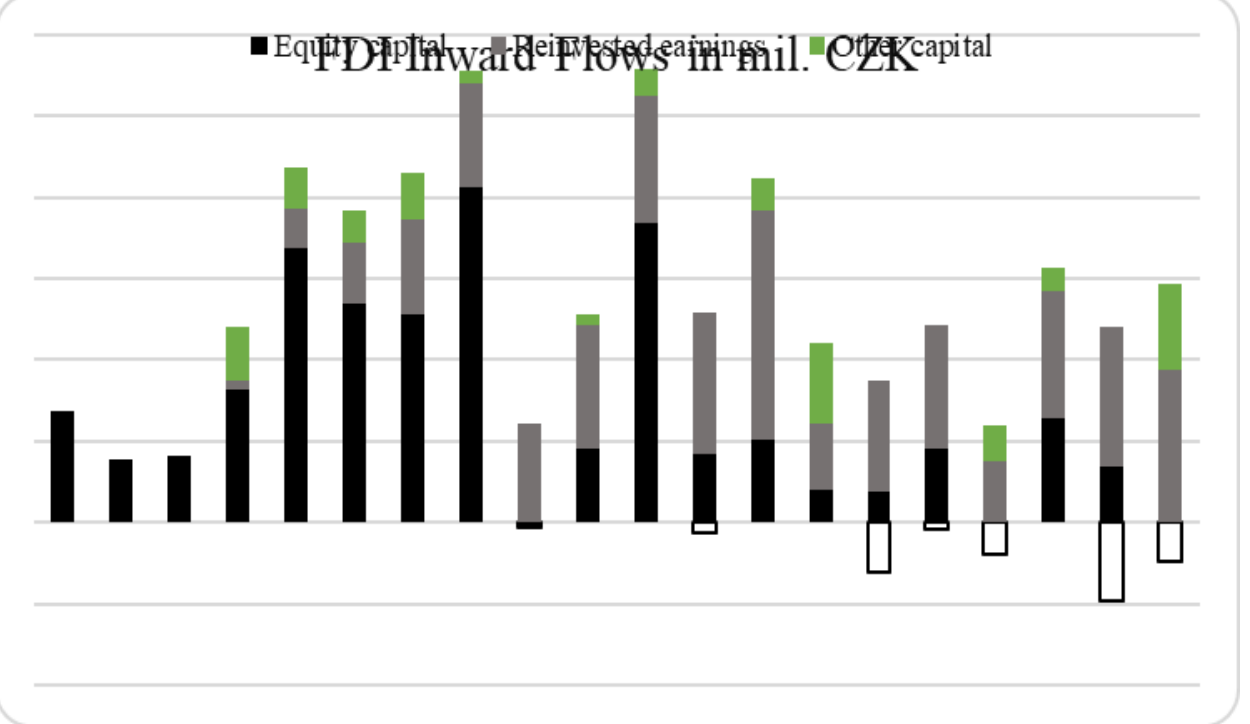

Source: $w w w . c n b . c z$

Another measure of quality of macroeconomic environment is frequently characteristic of countries attractiveness for international investors - the Foreign Direct investment. Nevertheless, the volume of FDIs reacts not only to economic stability perceived by international companies and conditions for entrepreneurs. Important feature is also the quality of business environment characterized by Business environment ranking the Czech Republic is on 28th place $^{7}$.

FDIs have been important for the economy in late 1990s. Nowadays their importance reverses as foreign companies repatriate their profits that have been earned in this territory and less money remains in the Czech Republic. ${ }^{8}$

After initial reform of accounting regulations, which commenced at the beginning of the 1990s, Czech regulations were first transformed from centrally planned rules to market-based principles. Subsequently, IFRS was introduced to Czech accounting as a voluntary style of reporting in 2003 and 2005. At the same time there remains an obligation to calculate the tax base according to Czech national GAAP for tax purposes. This obligation persists to date. Therefore, as the Czech companies do not clearly see any clear benefits of IFRS introduction, they are still hesitant to invest in this new style of reporting.

\footnotetext{
${ }^{7}$ http://www.iberglobal.com/files/business_climate_eiu.pdf

${ }^{8}$ http://www.statistikaamy.cz/2015/12/dve-desetileti-primych-investoru-v-cesku/
} 
In general, the number of companies reporting according to IFRS is not much, even though their percentage is increasing. There are three principal reasons why using IFRS is less frequent:

(1) The capital market where IFRS reporting would be compulsory is not very active,

(2) Industrial relations with foreign entities do not necessarily require more frequent use of IFRS, and

(3) Perceptions of extra costs associated with implementation of IFRS were verified by recent research survey on a representative sample of 258 Czech companies. The reason for extra perceived costs is valid particularly for SMEs but not for subsidiaries of foreign parent companies, where these costs were already covered by the needs of consolidation. In these cases, the lack of interest in IFRS reporting was caused by lack of perceived benefits (Kubičková, \& Jindřichovská, 2016; Korbelová, 2017 Forthcoming).

\section{Accountants and Accounting Profession in Context of China and the Czech Republic}

Early study on accounting profession in China has been written by Ping in 1999 . His paper traces changes in the organisation and regulation of accountancy practitioners in China during the twentieth century, with focus on the post-1978 period. It highlights the changing balance over time, between state, market and community as principles for organising practitioners. Despite the significant movement towards a market economy, the country still remains in the midst of a period of transformation both in Chinese society as a whole and accountancy in particular. At present, the governmental bodies preserve big influence over Chinese accountancy through its control of Chinese accountants.

Tang (2000) summarized the gradual change of accounting practices and impact on accounting profession. The accounting system was inherited from the former Soviet Union, which was principally serving the planning purposes of centrally controlled economy. Driving force of changes was Chinese presence in the international trade. Since 1980s the accounting regulation was progressively changing to serve the growing market economy. The changes included its institutional background as well as the accounting profession.

The main users of accounting system were identified as the government; investors, creditors, other relevant parties outside the enterprises and company management. As to accounting profession the author states that many accountants in China did not have a thorough understanding of theoretical reasoning behind the conceptual frameworks and many accountants in China did not understand how to change the existing accounting practices to achieve conformity with the new basic accounting standard inspired by Western tradition. Typical feature of Chinese accounting system is so called "responsibility feature" typical characteristic that was dominant 
in China for many years. This was although not serving the new market economy, where the real value needs to be considered as well.

The new basic accounting standard went public in 1992. At that time some government officials found it strange and criticized the new system as "exotic". Nevertheless, it was the Chinese Accounting Society, China's largest academic body that first initiated the accounting standards program and raised the issue of internationalization. However, the Chinese accounting association also needs some innovation. It was revealed that 52 percent of CPAs are 60 or older and only 18 percent of CPAs hold university degrees (Tang, 2000).

Accounting practice, research, and education in China are in a period of rapid change. The general trend goes from a planned-economy oriented, self-contained tradition toward an outward, open attitude. Internationalization is recognized as an appropriate route through which the level of accounting must be upgraded. Some important measures have been taken to improve the competency of accountants. The unified CPA examination is administered each year, with hundreds of thousands of candidates sitting the examination (Tang, 2000). Although the latest experience shows that improvement has been great and fast, there is still long way to go and the major role will be played by academics.

Recent changes in Chinese accounting profession were analysed by Yee, 2009 and 2012. The author states that the dynamic nature of the state-accounting profession relationship has been mostly explored within the context of western democracies and in context of capitalist economy. This paper contributes by examining the influence of the state power running over the Chinese public accounting profession during the1990s and considers the specific cultural and political environment in China. The paper employs a corporatist framework combined with Neo-Marxist concept of hegemony authored by Antonio Gramsci. This paper provides insights into the power relation between the state and the accounting profession. It also elucidates the ideological influence of the state on the development of the accounting profession. The empirical investigation also pays attention to the intraprofessional conflicts that took place in the 1990s. Finally, it provides further insights into the dynamic of the relation between state and accounting profession in that era.

To bring in the basic background to build up the background for our comparison, we provide a brief account of position of accountants and accounting profession in the Czech Republic. Accounting was always a practical discipline. Historically the Czech Republic was formally a part of Austro-Hungarian Empire with long its manufacturing tradition where accounting served the needs of industrial economy. The profession is growing from central European tradition and its features were recently characterized in Schroll, 1995; Seal, Sucher, \& Zelenka, 1995 and 1996; Sucher et al., 2005; Hellström, 2006, McGee, \& McGee, 2008, Albu et al., 2013, Strouhal, 2009, and in Jindřichovská, \& Kubíčková, 2015. 
One can find common features with centralized nature of Chinese environment and the conditions of development of the Czech accounting profession in modern age. Since 1950s the Czech accounting theory and practice was regulated mostly by the state with dominant institutional influence of Ministry of Finance as well.

\section{Research Methodology}

The investigation assumed used in prior literature that the rule-based accounting systems is perceived as difficult and time-consuming and it has to be converted to principle-based system to overcome the inertia of accounting way of thinking and accounting practice. We suggest that ten years since the transition to principle-based accounting standards is a relatively long period so that accounting attitudes could have been significantly transformed at least in some features. It can also be supposed that such change represents some of the first expressions of transition from planned system to market economy.

To achieve the aim and perform the comparison, we have used the questionnaire method enquiring two study groups. Both groups were formed by students of the first semester of the academic year 2016/2017 from the faculty of economic sciences at University of Finance and Administration in Prague Czech Republic. The first group consisted of 32 students from the Peoples Republic of China and the second group consisted of 32 students mainly from the Czech Republic (but also from Russia and other countries of the former Soviet Union). Students in both groups were high school graduates, coming from bigger cities and middle-class families, whose parents mostly work in the administrative functions. It was therefore plausible to assume that the respondents could have certain knowledge of economic issues and thus be able to form their own opinion in this matter. ${ }^{9}$

The used research method was the questionnaire. The questions in the survey were formulated as employing hypotheses based upon prior literature enlisted further.

1. Features corresponding to the role of accounting in a centrally controlled economy still dominate in accounting opinion of Chinese students as members of Chinese society.

2. The perception of the role of managers and owners in company management system reflects elements of centrally managed system moderated by features of its original cultural environment.

The questionnaire containing four parts along the lines of our general interest was presented to both groups of respondents. The first part provided identification of respondents including their financial reporting experience either their own personal experience or experience of their parents. The following part was organized in three

\footnotetext{
${ }^{9}$ We are aware that our sample is rather limited, but we have used everythingthat was at our disposal at the time. We hope to use much larger sample in our next investigation.
} 
steps, which gradually extended our findings. In the second part we inquired (a) whether the respondent had knowledge or any experience with accounting and tax systems. Subsequently we inquired about (b) the perception and evaluation of accounting and accounting profession. In the final part we have experimentally tested (c) the approach to solution of selected accounting situations. Formulation of questions and model situations were based on findings of Tsakumis, 2007; Ryan, 2006; Prochazka, 2008 and Strouhal, \& Bonaci, 2014.

Data were first collected through the questionnaire, then coded and subsequently analysed using descriptive statistics (i.e. mean, and standard deviation) to analyse the responses. To measure the degree of similarity of the two sets of responses of groups surveyed we employed the correlation coefficient and the F-test. The F-test was chosen to test the compliance of data sets that cannot obtain negative values, which corresponds tote nature of acquired data.

\section{Results}

Perception of accounting and accounting profession was evaluated in four steps. In the first step we investigated how respondents understand the role of information provided by financial statements and how they perceive and evaluate accounting and accounting profession. We wanted to find out what is the main goal of accounting and importance of financial statements according to our respondents. The answer consisted of selection of five proposed variant answers with values of 1 to 5 . The proposed answers and the average values are presented in Table 2.

Table 2. The main goal of accounting and importance financial statements

\begin{tabular}{|l|l|l|l|}
\hline & & $\begin{array}{l}\text { Chinese } \\
\text { group }\end{array}$ & $\begin{array}{l}\text { Czech } \\
\text { group }\end{array}$ \\
\hline A & $\begin{array}{l}\text { Providing information about processes in the company for } \\
\text { its management and administration }\end{array}$ & 1.71 & 1.78 \\
\hline B & $\begin{array}{l}\text { Providing information on the company's financial situation } \\
\text { and its performance for the stock exchange transactions and } \\
\text { other investors activities }\end{array}$ & 1.88 & 2.03 \\
\hline C & $\begin{array}{l}\text { Providing information for determination of the amount of } \\
\text { tax liability }\end{array}$ & 2.13 & 1.88 \\
\hline D & Providing information for staff evaluation and remuneration & 2.31 & 2.35 \\
\hline F & Providing information for managers' evaluation & $\mathbf{2 . 4 4}$ & $\mathbf{2 . 5}$ \\
\hline G & $\begin{array}{l}\text { Providing information for banks and other creditors for the } \\
\text { purpose of assessing the borrowers' creditworthiness }\end{array}$ & 2.19 & 2.16 \\
\hline H & $\begin{array}{l}\text { Providing information to increase the effectiveness of the } \\
\text { internal operations of the company }\end{array}$ & 2.28 & 2 \\
\hline Correlation & Others & $\mathrm{x}$ & $\mathrm{x}$ \\
\hline F-test & & 0.7855 & \\
\hline
\end{tabular}

Source: own investigation. 
The main importance of the accounting and accounting information was most often perceived with the use in management evaluation (e) and decision-making of managers (d). The responses of both groups did not differ significantly, which was confirmed by the value of F-test. Interesting are the differences in the assessment of b) and c) value between the groups. Higher importance of financial information for capital markets and investors activities was identified by the Czech students, while the by Chinese group of students attributed higher importance to the tax purposes of financial statements.

This finding of Czech group is interesting because capital markets play very minor role in financing of companies in the Czech Republic, whereas dominant bulk of funding is provided by bank sector in accordance with historical Austro-Hungarian tradition. It can be also considered as a reflection of the predominant central elements in Chinese economy and general accounting attitude.

The next question was aimed to discover the opinion on the significance of financial statements and financial information for set of users. The significance was classified in five degrees: a) exclusive importance, b) very important, c) indifference (I don't know), d) minor importance or negligible importance, and e) no importance). The groups of users and related results are presented in Table 3.

Table 3. The importance of financial statements for set of users

\begin{tabular}{|l|l|l|l|}
\hline & & $\begin{array}{l}\text { Chinese } \\
\text { group }\end{array}$ & $\begin{array}{l}\text { Czech } \\
\text { group }\end{array}$ \\
\hline a & Top managers of company & 1.72 & 1.73 \\
\hline b & Managers at various management levels & 2.00 & 2.10 \\
\hline c & Investors - interested in buying shares in a company & 1.56 & 1.96 \\
\hline e & Owners of the company. shareholders & 1.69 & 1.77 \\
\hline f & $\begin{array}{l}\text { Banks and other financial institutions providing } \\
\text { credit and other financial services }\end{array}$ & 1.69 & 1.87 \\
\hline g & Suppliers & $\mathbf{2 . 0 9}$ & $\mathbf{2 . 3 4}$ \\
\hline h & Customers & $\mathbf{2 . 1 6}$ & $\mathbf{2 . 5 2}$ \\
\hline i & Local and regional authorities & 2.00 & 2.29 \\
\hline j & Financial and tax authorities & 2.03 & 1.79 \\
\hline k & Employees & $\mathbf{2 . 2 8}$ & $\mathbf{2 . 7 9}$ \\
\hline Correlation & Other institutions & x & x \\
\hline F-test & & 0.9605 & \\
\hline
\end{tabular}

Source: own investigation

There is not a great difference in perceptions of accounting profession between the groups, as confirmed by the value of F-test. The main importance of financial information according to Chinese students as well as Czech students is perceived by 
employees and subsequently by consumers and suppliers. We find it very interesting that the "top management of company" scores quite low in this question in both Czech and Chinese subsets. For Chinese group the lowest importance has been earmarked to potential investors! This can be perceived as a reflection of remaining insignificant role of capital market in Chinese economy, which is also a bit puzzling. In the following part we used an experiment and we have enquired with the use of three model situations. We wanted to find whether there are any differences in proposed solutions of simple accounting situations. The first question tested the proclivity to caution in reporting of content as a sign of higher conservatism. The other aspect was the reason of the solution - lowering tax or proper information. The model situation was described as is follows:

"You are in a position of company's accountant and you have to solve the following issue: The customer has to pay to your company for product delivery. However, the customer got into uneasy financial position and asks for extension of payment. Their financial situation is becoming very difficult and it is possible that they will not pay the full amount. The end of reporting period is approaching and the value of related receivable will be reported in your balance sheet. What accounting treatment of this situation you will recommend?" (highlight the chosen solution a), b) or c).

The results of both groups are presented in Table 4 .

Table 4. Compliance with rules of financial reporting

\begin{tabular}{|c|c|c|c|c|c|}
\hline & & \multicolumn{2}{|c|}{ Chinese group } & \multicolumn{2}{|c|}{ Czech group } \\
\hline & & Number & $\%$ & Number & $\%$ \\
\hline A & $\begin{array}{l}\text { You reduce the amount of Receivables } \\
\text { (creating adjustment), because the } \\
\text { original amount of Receivables would be } \\
\text { improperly expressed the volume of } \\
\text { firm's assets with regard to the risks that } \\
\text { emerged. }\end{array}$ & 5 & $15.6 \%$ & 9 & $32.1 \%$ \\
\hline B & $\begin{array}{l}\text { You reduce the amount of Receivable } \\
\text { (creating adjustment), because reduction i } \\
\text { the amount - adjustments - can reduce th } \\
\text { tax base and tax obligations. }\end{array}$ & 16 & $50.0 \%$ & 12 & $42.9 \%$ \\
\hline $\mathrm{C}$ & $\begin{array}{l}\text { You do not reduce the amount of } \\
\text { Receivables (you do not create the } \\
\text { adjustment) because the reduction in the } \\
\text { item did not occur and only future } \\
\text { development will show what will has to } \\
\text { be recorded in the books. }\end{array}$ & 11 & $34.4 \%$ & 7 & $25.0 \%$ \\
\hline Correlation & & 0.5531 & & & \\
\hline F-test & & 0.4285 & & & \\
\hline
\end{tabular}

Source: own investigation. 
The answers were similar in both groups - the solution with the highest frequency represents the willingness to report with respect to accounting rules and with the same reason - to reduce tax obligation. The role of tax in accounting and the impact on the accounting information was confirmed in both national contexts. The distribution of responses is a little different - as confirmed by the value of F-test. Greater tendency towards conservatism, and greater attention to the risk in the information provided can be seen in the group of Czech students (32.1per cent of the answers), while the tendency to materiality of the information (as a part of "responsibility feature") can be seen in a group of Chinese students (34.4 per cent of answers). The next situation was aimed to test the role of accounting rules in the accountant's decision-making. The core of the model situation was as follows:

"You are in a position of the company's accountant and you have to solve the following situation: A new partner has joined the company. His contribution to equity of the company will be a truck as non-monetary endowment. You have to decide on the accounting treatment of this operation. How will you deal with this situation?" (highlight one of the solutions a) - h) which correspond to your opinion). The options $\mathrm{a})-\mathrm{h}$ ) and the corresponding results reached in both groups are presented in Table 5.

Table 5. The role of regulation in accountants' decisions

\begin{tabular}{|c|c|c|c|c|c|}
\hline & & \multicolumn{2}{|c|}{ Chinese group } & \multicolumn{2}{|c|}{ Czech group } \\
\hline & & Number & $\%$ & Number & $\%$ \\
\hline $\mathrm{a}$ & $\begin{array}{l}\text { You ask for advice of an accountant } \\
\text { working in another company, how did he } \\
\text { deal with this situation }\end{array}$ & 3 & $9.7 \%$ & 4 & $13.8 \%$ \\
\hline $\mathrm{b}$ & $\begin{array}{l}\text { You will search for information in textbook } \\
\text { and interpretative materials (on internet etc.) }\end{array}$ & 5 & $16.1 \%$ & 4 & $13.8 \%$ \\
\hline $\mathrm{c}$ & $\begin{array}{l}\text { You will search for information in } \\
\text { accounting standards and interpretations } \\
\text { issued by the Union of Accountants }\end{array}$ & 8 & $25.8 \%$ & 0 & $0.0 \%$ \\
\hline $\mathrm{d}$ & $\begin{array}{l}\text { You will search for information in the } \\
\text { Accounting Law and other legislation } \\
\text { governing accounting, }\end{array}$ & 9 & $29.0 \%$ & 11 & $37.9 \%$ \\
\hline $\mathrm{e}$ & $\begin{array}{l}\text { You know the situation and you can solve } \\
\text { this situation based on this knowledge, }\end{array}$ & 4 & $12.9 \%$ & 5 & $17.2 \%$ \\
\hline $\mathrm{f}$ & $\begin{array}{l}\text { You ask a consulting firm to provide you } \\
\text { with the information. }\end{array}$ & 2 & $6.5 \%$ & 1 & $3.4 \%$ \\
\hline $\mathrm{g}$ & $\begin{array}{l}\text { You ask the tax advisor for relevant } \\
\text { information }\end{array}$ & 0 & $0.0 \%$ & 4 & $13.8 \%$ \\
\hline $\mathrm{h}$ & Other solutions (no answer) & 1 & $\mathrm{x}$ & 3 & $\mathrm{x}$ \\
\hline Correlation & & 0.3615 & & & \\
\hline F-test & & 0.7019 & & & \\
\hline
\end{tabular}

Source: own investigation. 
In the table, the most similar and the most contrasting solutions are highlighted. The most frequent suggestion was to consult the legal rules governing the accounting. It was the most common solution both in the Czech and Chinese group. The greater differences occurred in the solution used the recommendation of the Union of accountants. While $25 \%$ of the respondents chose this solution in the Chinese group, none of the respondents opted for this solution in the Czech group. This can be understood as an indicator of the changing position of professional accounting in Chinese economy which was strengthened by the process of adoption of the new accounting standards.

In the final model question, we tested the views on possible misuse of information in the financial statements and hence the perception of importance of financial information. The respondents should choose one of the suggested statements about the nature of financial information:

"The information in financial statements - in your opinion ((highlight one of the solutions a) $-e)$ )". The offered responses a) - e) and results reached in both groups are presented in Table 6.

Table 6. The character of financial information

\begin{tabular}{|c|c|c|c|c|c|}
\hline & & \multicolumn{2}{|c|}{ China course } & \multicolumn{2}{|c|}{ Czech course } \\
\hline & & Number & $\%$ & Number & $\%$ \\
\hline A & $\begin{array}{l}\text { Is strongly private and should be used } \\
\text { only for the owners and managers. }\end{array}$ & 4 & $9.8 \%$ & 12 & $42.9 \%$ \\
\hline $\mathrm{B}$ & $\begin{array}{l}\text { Is public, available for everyone who } \\
\text { wants to collaborate with the company }\end{array}$ & 10 & $32.3 \%$ & 5 & $17.9 \%$ \\
\hline C & $\begin{array}{l}\text { Is sensitive and its publishing exposes } \\
\text { the company to danger }\end{array}$ & 9 & $29.0 \%$ & 1 & $3.6 \%$ \\
\hline $\mathrm{D}$ & $\begin{array}{l}\text { Presents a picture of the of company's } \\
\text { performance and should be publicly } \\
\text { available }\end{array}$ & 4 & $12.9 \%$ & 3 & $10.7 \%$ \\
\hline $\mathrm{E}$ & $\begin{array}{l}\text { Presents the information important for } \\
\text { public authorities and national economic } \\
\text { statistics and should only be provided to } \\
\text { these institutions. }\end{array}$ & 14 & $45.1 \%$ & 7 & $25.0 \%$ \\
\hline Correlation & & -0.7033 & & & \\
\hline F-test & & 0.9246 & & & \\
\hline
\end{tabular}

Source: own investigation.

The answers and their distribution were quite different in both groups. Most Chinese respondents consider the financial information as important for public authorities and national statistics. To the contrary most Czech respondents consider the financial information strongly private and available only for the firm owners and managers. Only a few students agreed to this view in the Czech group. Relatively great number of Chinese students (29.0 per cent) considers the financial information as sensitive and its publishing could expose the company to danger. And the same 
number (32.3 per cent) of the Chinese students the financial information considers as publicly useful and important for the company's collaborates. The difference in answers is confirmed negative value of correlation and the value of F-test.

The last model question concerned possible reason for earnings management and justification of this manipulation. The respondents should solve this model task:

"The chief accountant of company has decided to use all available opportunities given within the accounting rules to report the lowest possible earnings. You perceive his efforts to report the lowest profit as: ... (Please, choose the most appropriate suggestions in table below)." Offered solution and answers are presented in Table 7.

Table 7. The earnings management and its justifications

\begin{tabular}{|c|c|c|c|c|c|}
\hline & & \multicolumn{2}{|c|}{ China course } & \multicolumn{2}{|c|}{ Czech course } \\
\hline & & Number & $\%$ & Number & $\%$ \\
\hline A & $\begin{array}{l}\text { Reasonable, because he company will } \\
\text { not need to pay large dividends, }\end{array}$ & 4 & $12.5 \%$ & 2 & $7.7 \%$ \\
\hline B & $\begin{array}{l}\text { Reasonable, because he company will } \\
\text { not have to pay high taxes, }\end{array}$ & 5 & $15.6 \%$ & 14 & $53.8 \%$ \\
\hline $\mathrm{C}$ & $\begin{array}{l}\text { Unwise because it decreases the share } \\
\text { price of the company on the stock } \\
\text { exchange, }\end{array}$ & 5 & $15.6 \%$ & 3 & $11.5 \%$ \\
\hline $\mathrm{D}$ & $\begin{array}{l}\text { Unwise because it will worsen the } \\
\text { company's credibility in the eyes of } \\
\text { banks and lower credit availability, }\end{array}$ & 18 & $56.3 \%$ & 7 & $26.9 \%$ \\
\hline Correlation & & 0.1007 & & & \\
\hline F-test & & 0.9961 & & & \\
\hline
\end{tabular}

Source: own investigation.

The responses are quite different for each group. The most frequent answer in the Chinese group was the refusing to lower the earnings to the lowest possible figure justified by possible restriction of access to credit. The most frequent answer in the Czech group considered reducing profits as appropriate measure accompanied with justification for lower tax liability. It can be explained as a reflection of the growing role of banks in the current stage of transformation in Chinese economy and of the reflection of the role of accounting in the Czech economy. The differences in the distribution of answers are also confirmed by the value of correlation and corresponding F-test.

\section{Conclusion}

Our results confirmed validity of our hypothesis of existence of different perception and related opinion on accounting profession and role of accounting corresponding to nationality of respondents. We found that there are differences both in opinions on the role of accountants in business on accounting profession and model business situations. The results of this questionnaire survey revealed some differences in 
opinion of respondents' opinions and approaches representing different national backgrounds.

As to the results of our qualitative research, the answers varied significantly in three of the six questions on attitude of accountants, but in three others they did not significantly differ. The key differences were revealed in issues of (1) the perception of the nature of financial information, (2) the role of a professional organization and (3) in the approach to distortion of financial information. Although the results of our research are for number of reasons mainly indicative, some predicted differences can be accredited to them. Because of these, it can be concluded that the hypotheses formulated for this research have been confirmed.

Limitations of our findings are in several levels. The first is the size and structure of both groups of respondents. As the respondents were the first-year university students from China and from the Czech Republic. The students were quite young and did not have to have firm opinion on some accounting issues. The second limitation is the nature of used questions in the questionnaire and their reliability to portray researched characteristics. The final reservation may be expressed to the wording of suggested answers or solutions, which sometimes may not be interpreted unambiguously.

Direction of future research: This qualitative research is very informative and rich in its nature; we recommend repeating the research in future years and use more experienced students where their accounting opinion is more firmly settled. Interesting could be also to find students' opinion on further development of accounting profession and perception of accounting jobs.

\section{References:}

Albu, C.N., Albu, N., Pali-Pista, S.F., Gîrbină, M.M., Selimoglu, S.K., Kovács, D.M., Lucacs, J., Mohl, G., Mullerova, L., Pasekova, M., Sipahi, B., Strouhal, J. and Arsoy, P.A. 2013. Implementation of IFRS for SMEs in emerging economies: Stakeholder perceptions in the Czech Republic, Hungary, Romania and Turkey. Journal of International Financial Management \& Accounting, 24(2), 140-175.

Allen, C.L. 2004. Business students' perception of the image of accounting. Managerial Auditing Journal, 19(2), 235-258.

Buchan, H.F. 2005. Ethical decision making in the public accounting profession. Journal of Business Ethics, 61(2), 165-181.

Byrne, M. and Willis, P. 2005. Irish secondary students' perceptions of the work of an accountant and the accounting profession. Accounting Education: an international journal, 14(4), 367-381.

Carnegie, G.D. and Napier, J.C. 2010. Traditional accountants and business professionals. Accounting, Organizations and Society, 35(3), 360-376.

Hellström K. 2006. The value relevance of financial accounting information in a transition economy: The case of the Czech Republic. European accounting review, 15(3), 325-349, dx.doi.org/10.1080/09638180600916242. 
Huang, F. 2003. Policy and Practice of the Internationalization of Higher Education in China. Journal of Studies in International Education, 7(3), 225-240.

ICAS, 2010. Chinese accounting reform: Towards a principles-based global regime. (Edinburg).

Jindřichovská, I. and Kubíčková, D. 2015. Czech accounting academia and practice: historical roots and current issues. Accounting and Management Information Systems, 14(2), 328-361.

Kloudová, J., 2006. Lisbon Strategy and the Competitiveness of the European Union in the Context of China as a Newly Emerging Power.

Korbelová, M., 2017. Financing of small and medium sized enterprises and the possibility to gain external funding when the unit uses the International Financial Reporting Standards (IFRS) in the Czech Republic. Forthcoming.

Kubíčková, D. and Jindřichovská, I. 2016. The comparability and reliability of financial information in the sector of Czech SMES (ten years of IFRS as a part of Czech accounting context)“, European Research Studies Journal, 19(4), 64-77.

Krugman, P. 1994. The myth of Asia's miracle. Foreign affairs, 62-78.

Krugman, P. 2010. Taking on China. New York Times.

Krugman, P. 2011. The new economic geography, now middle-aged. Regional Studies, 45(1), 1-7.

Liapis, K., Thalassinos, I.E. 2013. A Comparative Analysis for the Accounting Reporting of "Employee Benefits" between IFRS and other Accounting Standards: A Case Study for the Biggest Listed Entities in Greece. International Journal of Economics and Business Administration, 1(1), 91-116.

MacGregor, M., Pelikánová, R. 2014. Selected current aspects and issues of European integration, (Key Publishing: Ostrava).

MacGregor, M., Pelikánová, R., 2017. European Myriad of Approaches to Parasitic Commercial Practices. Oeconomia Copernicana, 8(2), 167-180, doi: 10.24136/oc.v8i2.11

McGee, R.W. and McGee, W.R. 2008. Accounting reform in transition and developing economies. Springer. Accounting Reform in the Czech Republic.

OECD, 2016. Education in China a snapshot. https://www.oecd.org/china/Education-inChina-a-snapshot.pdf

Ping Hao, Z. 1999. Regulation and organisation of accountants in China. Accounting, Auditing \& Accountability Journal, 12(3), 286-302.

Qian, Y., and Stiglitz, J. 1996. Institutional innovations and the role of local government in transition economies: the case of Guangdong province of China. Reforming Asian socialism: The growth of market institutions, 175-193.

Prochazka, D. 2008. Decrease of Asset Value - Specific expression of the caution principle in financial statements. In proceedings: Problems of theory and methodology of accounting, control and analysis, 291-302.

Ryan, S.G. 2006. Identifying Conditional Conservatism. European Accounting Review, 15(4), 511-525.

Seal, W., Sucher, P. and Zelenka, I. 1995. The changing organization of Czech accounting. European Accounting Review, 4(4), 659-681.

Seal W., Sucher P. and Zelenka, I. 1996. Post-socialist Transition and the Development of an Accountancy Profession in the Czech Republic. Critical Perspectives on Accounting, 7(4), 485-508.

Schroll, R. 1995. The new accounting system in the Czech Republic. European Accounting Review, 4(4), 827-832. 
Stiglitz, J.E., 2008. China: Towards a new model of development. China Economic Journal, $1(1), 33-52$.

Strouhal, J. 2009. Reporting Frameworks for Financial Instruments in Czech: Czech Accounting Practices versus International Financial Reporting Standards. WSEAS Transactions on Business and Economics, 7(6), 352-361.

Strouhal, J. and Bonaci, G.C. 2014. Accounting Harmonization trends from Perspective of Czech Professional Accountants. In: Conference proceedings of International Research Conference on Business, Economics and Social Sciences, December, Dubai, UAE, 56-69.

Sucher, P., Kosmala, K., Bychkova, S., and Jindrichovska, I. 2005. Introduction: Transitional economies and changing notions of accounting and accountability. European Accounting Review, 14(3), 571-577.

Tang, Y. 2000. Bumpy road leading to internationalization: A review of accounting development China. Accounting Horizons, 14(1), 93-102.

Thalassinos, I.E. 2008. Trends and Developments in the European Financial Sector. European Financial and Accounting Journal, 3(3), 44-61.

Thalassinos, I.E., Deceanu, L. and Pintea, M. 2010. New Dimensions of Country Risk in the Context of the Current Crisis: A Case Study for Romania and Greece. European Research Studies Journal, 13(3), 225-236.

Thalassinos, I.E., Liapis, K. and Thalassinos, E.J. 2014. The role of the rating companies in the recent financial crisis in the Balkan and black sea area. Chapter book in Economic Crisis in Europe and the Balkans, 79-115, Contributions to Economics, Springer International Publishing, DOI: 10.1007/978-3-319-00494-5-6.

Thalassinos, I.E. and Liapis, K. 2014. Segmental financial reporting and the internationalization of the banking sector. Chapter book in, Risk Management: Strategies for Economic Development and Challenges in the Financial System, (eds), D. Milos Sprcic, Nova Publishers, 221-255, ISBN: 978-163321539-9; 978163321496-5

Tsakumis, G.T. 2007. The Influence of Culture on Accountants' Application of Financial Reporting Rules. Abacus, 43(1), 27-48. Doi: 10.1111/j.1467-6281.2007.00216.x

Wang, J.H.Y. and Guthrie, T.J. 2004. Modelling the effects of intrinsic motivation, extrinsic motivation, amount of reading, and past reading achievement on text comprehension between US and Chinese students. Reading research quarterly, 39(2), 162-186.

Wang, F. and Mao, Q. 2017. Spatial Dynamics of Chinese Manufacturing Industries: Comparative Advantage versus New Economic Geography. Applied Economics and Finance, 4(3), 30-46.

World Bank, 2003. Czech Republic: Accounting and Auditing. (World Bank: Washington, DC) https://openknowledge.worldbank.org/handle/10986/14464 License: CC BY 3.0 IGO.

Yihong, G., Yuan, Z., Ying, C., and Yan, Z. 2007. Relationship between English learning motivation types and self-identity changes among Chinese students. Tesol Quarterly, 41(1), 133-155.

Yee, H. 2009. The re-emergence of the public accounting profession in China: A hegemonic analysis. Critical Perspectives on Accounting, 20(1), 71-92.

Yee, H. 2012. Analyzing the state-accounting profession dynamic: Some insights from the professionalization experience in China. Accounting, Organizations and Society 37, 426-444. 